OPEN ACCESS

\section{Short-term changes in the northwest African Upwelling System induced by Saharan dust deposition events}

To cite this article: A G Ramos et al 2009 IOP Conf. Ser.: Earth Environ. Sci. 7012019

View the article online for updates and enhancements.
Related content

- ASTRONOMICAL SITE TESTING IN THE
$\frac{\text { CANARY ISLANDS }}{\text { Bennet McInnes and Merle F. Walker }}$
- African dust deposition to Florida: How
$\frac{\text { well do dust models perform? }}{\text { J M Prospero and W Landing }}$
- Study on the surface stress and the
$\frac{\text { surrounding dust deposition of solar }}{\text { photovoltaic module }}$
Mingzhi Zhao, Hao Sun, Yiming Miao et al.

Recent citations

- Objective identification of synoptic
$\frac{\text { meteorological patterns favouring African }}{\text { dust intrusions into the marine boundary }}$
$\frac{\text { laver of the subtropical eastern north }}{\text { Atlantic region }}$
S. Alonso-Pérez et al 


\title{
Short-Term Changes in the Northwest African Upwelling System induced by Saharan Dust Deposition events
}

\author{
A G Ramos ${ }^{1}, \mathbf{E}$ Cuevas $^{2}, C_{\text {Pérez }}^{3}, \mathrm{~J} \mathrm{M} \mathrm{Baldasano}^{3,4}, \mathrm{~J} \mathrm{Coca}^{1}, \mathrm{~A}$ Redondo $^{1}, \mathrm{~S}$ \\ Alonso-Pérez ${ }^{2,5}$, J Bustos $^{2}$ and $\mathrm{S}$ Nickovic $^{6}$ \\ ${ }^{1}$ SeaSnet Canarias. Dpto. de Biología (Univ. of Las Palmas de Gran Canaria). Canary \\ Islands, Spain. \\ ${ }^{2}$ Izaña Atmospheric Research Center. Agencia Estatal de Meteorología. Tenerife, \\ Spain. \\ ${ }^{3}$ Earth Sciences Department. Barcelona Supercomputing Center. Barcelona, Spain. \\ ${ }^{4}$ Laboratory of Environmental Modeling. Universitat Politècnica de Catalunya. \\ Barcelona. Spain \\ ${ }^{5}$ Institute of Earth Sciences "Jaume Almera", CSIC. Barcelona, Spain. \\ ${ }^{6}$ Atmospheric Research and Environment Branch. World Meteorological \\ Organization. Geneva, Switzerland. \\ E-mail: aramos@pesca.gi.ulpgc.es
}

\begin{abstract}
During the last 7-year period (2000-2006) atmosphere circulation changes show strong influences on the dust storm deposition dynamics and, as a result, on the primary production dynamics of the northwest African Upwelling System. From 2000 to 2006, the annual mean sea level pressure became higher ranging from 1014 to $1015 \mathrm{mb}$. Mean annual zonal wind intensity became higher (from 1.1 to $1.8 \mathrm{~m} \mathrm{~s}^{-1}$ ), while the mean annual meridional was reduced from 6.2 to $5.3 \mathrm{~m} \mathrm{~s}^{-1}$ at the north of the Canary Islands. Mean annual satellitederived AVHRR/NOAA SST recorded in the northwest African Upwelling became warmer in both locations, from $18.3^{\circ} \mathrm{C}$ to $18.8^{\circ} \mathrm{C}$ in Cape Ghir and from $19.5^{\circ} \mathrm{C}$ to $20.3^{\circ} \mathrm{C}$ north Canary Islands waters. $\mathrm{CHL}$ records from the SeaWiFS/OV-2 showed a different pattern trend. Mean annual CHL levels increased at Cape Ghir from $0.65 \mathrm{mg} \mathrm{m}-3$ to $0.9 \mathrm{mg} \mathrm{m}-3$ and significantly reduced from $0.59 \mathrm{mg} \mathrm{m}^{-3}$ to $0.31 \mathrm{mg} \mathrm{m}^{-3}$ at the north of the Canary Islands. Changes observed in the role of CHL during the last 7-years period could be associated to intensive dust deposition and exceptional weather warming observed in this area since 2000. However, this study focused on a 7-year period and conclusions on possible links between dust deposition and marine biochemistry activity cannot be generalized.
\end{abstract}

\section{Introduction}

Photosynthesis in the ocean is, by far, the most important biochemical process of conversion of Inorganic Carbon (IC) into biomass (Organic Carbon, OC). The OC generated through this primary production (photosynthetic) process is transferred to the higher trophic layer in superficial waters where most marine life develops. However, the excess of unused C (rejected) undergoes a progressive sinking to the bottom. In the deep ocean layers, this rejected OC can go through two processes: it is either recycled by the heterotrophic flora and transformed into reusable IC or it stays fixed as a sedimentary stratum at the bottom [1]. This cycle, however, requires some additional nutrients in high 
concentrations, mainly Nitrogen $(\mathrm{N})$ and Phosphorus (P). The availability (upwelling system) or nonavailability (oligotrophic oceanic waters) of any of these macronutrient elements ( $\mathrm{N}$ and $\mathrm{P}$ ) depends on the vertical mixing supply to upper waters or by diazotrophic nitrogen-fixing processes.

However, the absence of other available key nutrients such as Iron $(\mathrm{Fe})$ and Manganese $(\mathrm{Mn})$ can also limit the conversion of IC into OC. This micronutrient limitation is associated to its extremely low solubility (nanomolar levels) and are mostly supplied in the NE Atlantic by the exogenic dust deposition events $[2,3,4,5,6]$.

Thus, long-term trend changes on the concentration of these trace elements would change the primary production role in both poor oligotrophic and rich eutrophic oceanic areas. In this paper, we focus in preliminar long-term trend of geophysical and meteorological indicators in the northwest African waters during the warmest 7-years period of the century (2000-2006), and how this changes influence the dust deposition input and, for instance, the primary production role in both areas.

\section{Methodology}

Meteorological parameters, satellite images data and model dust deposition inputs were collected from january 2000 to December 2006 over the northwest African waters at two stations located at Cape Ghir (upwelling station) and north Canary Island (figure 1).

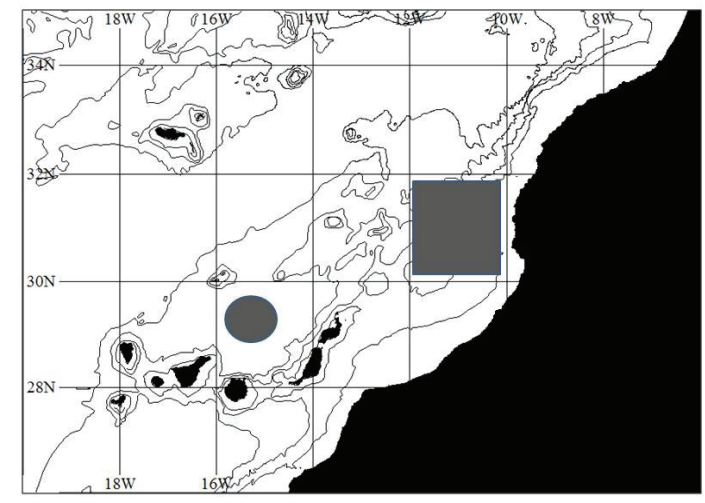

Figure 1. The northwest African Upwelling area. Data sets of dust deposition, SST and CHL were extracted from oligotrophic waters located to the north of the Canary Islands (grey circle) from upwelled waters located off Cape Ghir (grey square).

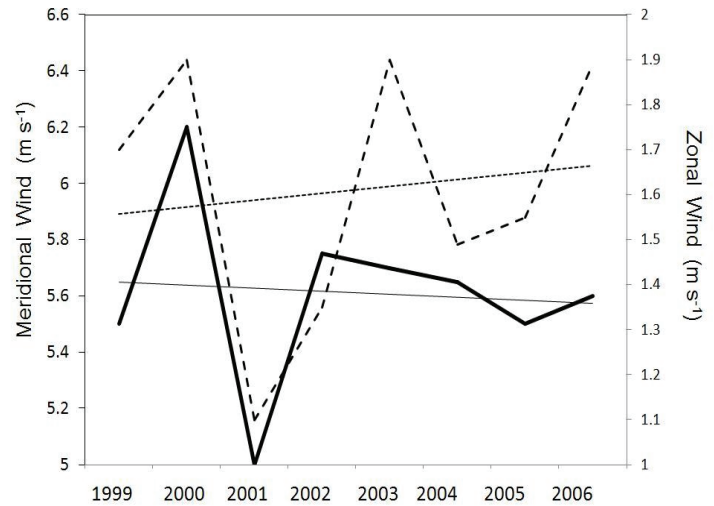

Figure 2. Annual mean meridional (solid line) and zonal (dashed line) wind speed series in the Northwest African Upwelling area from 1999 to 2006.

Wind components at $10 \mathrm{~m}$ height were obtained from the European Centre for Medium-Range Weather Forecasts (ECMWF) T511 L60 operational analysis at 00, 06, 12 and 18 UTC. We used the Dust REgional Atmospheric model (DREAM) of the Barcelona Supercomputing Center (BSC) $[7,8,9,10]$ to simulate predict the atmospheric cycle of mineral dust aerosol. The model incorporates advanced parameterizations of all the major phases of the atmospheric dust cycle, such as emission, diffusion, advection and deposition. All the model components are described in [11]. Satellite-derived parameters were obtained during the event: Sea Surface Temperature (SST) images were supplied by the Jet Propulsion Laboratory (JPL) PODAAC Pathfinder. Satellite-derived SeaWiFS/OV-2 chlorophyll-a (CHL) images were extracted from the NASA Ocean Colour Web. Data were projected on SMI cylindrical equidistant at different ground resolutions [12].

\section{Results and discussion}

Mean sea level pressure, AVHRR/NOAA SST and wind components obtained from the ECMWF showed the warmest 7-year period reported since 1912. From 2000 to 2006, the annual mean sea level 
pressure was higher ranging from 1014 to $1015 \mathrm{mb}$. This change on the atmospheric circulation influenced the zonal and meridional wind components dynamics. Mean annual zonal wind intensity became higher during the 7-year period (from 1.1 to $1.8 \mathrm{~m} \mathrm{~s}^{-1}$ ). However, the mean annual meridional winds were reduced from 6.2 to $5.3 \mathrm{~m} \mathrm{~s}^{-1}$ (figure 2).

The increase of the east-west component of the wind together with a reduction of the north trade wind component was translated into a change of the annual flux of Saharan dust over the northwest African Upwelling system. Annual average dry deposition flux of Saharan dust can range from 0.03 to $0.08 \mathrm{~g} \mathrm{~m}^{-2} \mathrm{~d}^{-1}$ or $1.7 \times 10^{6} \mathrm{t} \mathrm{yr}^{-1}$ [13]. Our DREAM model derived data showed that at the north Canary Islands station, the annual dry dust deposition data reduced from $0.12 \mathrm{mg} \mathrm{m}^{-2} \mathrm{~d}^{-1}$ (2000) to $0.10 \mathrm{~g} \mathrm{~m}^{-2}$ $\mathrm{d}^{-1}$ (2006) north Canary Islands. However, in the Cape Ghir location station DREAM model derived data showed that annual dry dust deposition data increased from $0.025 \mathrm{mg} \mathrm{m}^{-2} \mathrm{~d}^{-1}(2000)$ to $0.040 \mathrm{mg}$ $\mathrm{m}^{-2} \mathrm{~d}^{-1}$ (2006) (figure 3).

Mean annual satellite-derived AVHRR/NOAA SST recorded in the northwest African Upwelling becomes warmer. It ranged between $18.3^{\circ} \mathrm{C}(2000)$ to $18.8^{\circ} \mathrm{C}(2006)$ in the coastal eutrophic station located at Cape Ghir and from $19.5^{\circ} \mathrm{C}(2000)$ to $20.3^{\circ} \mathrm{C}(2006)$ in the oceanic oligotrophic station north Canary Islands waters (figure 4). Some authors [Ramos et al., 2005] revealed that in the Canarian waters, the SST ranges between $17^{\circ} \mathrm{C}$ in winter to $24^{\circ} \mathrm{C}$ in summer. However, some areas at the south of the Canarian waters presented SST peaks during this period (2004) of $28.5^{\circ} \mathrm{C}$, records never reported before.

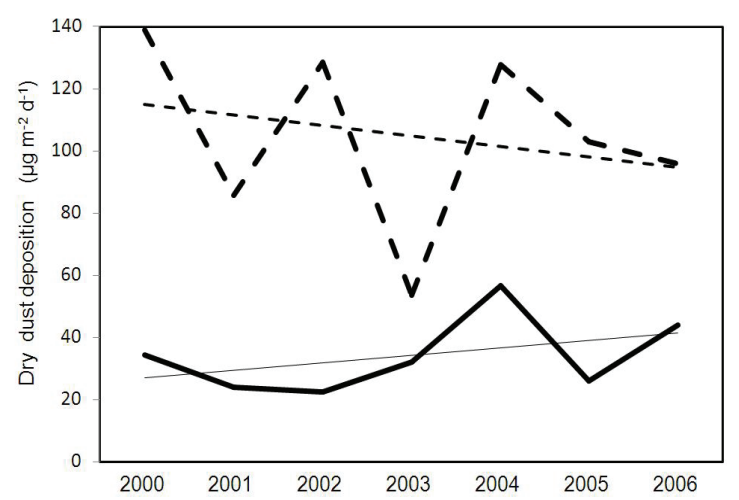

Figure 3. Annual mean DREAM modelled dry dust deposition at Cape Ghir (solid line) and north of the Canary Islands (dashed line) from 2000 to 2006.

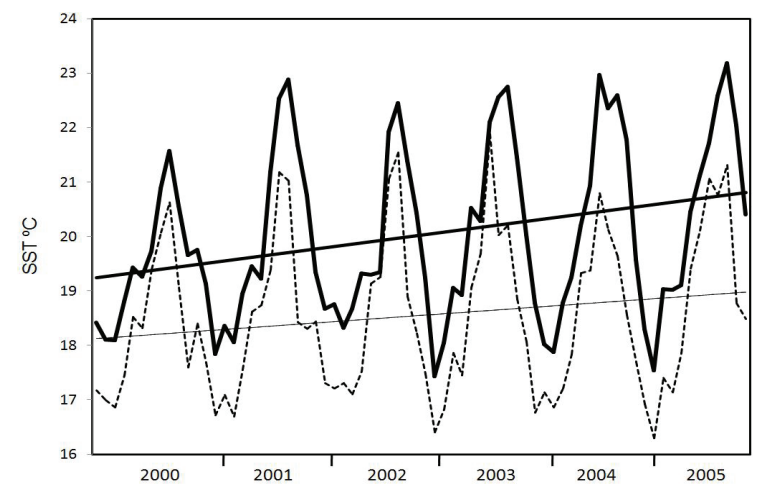

Figure 4. Annual mean satellite-derived AVHRR/NOAA SST data series at Cape Ghir (dashed line) and north of the Canary Islands (solid line) from 2000 to 2005.

Some studies $[1,14]$ investigated the mean annual cycles of CHL in this area, concluding that in the canarian oligrotrohic waters, values of mean annual CHL oscillated around $0.4 \mathrm{mg} \mathrm{m}^{-3}$. However, in the rich eutrophic upwelled waters of Cape Ghir the mean annual CHL levels arised to $0.8 \mathrm{mg} \mathrm{m}^{-3}$. As a result of the progressive increase of the SST observed in both Canary Island and Cape Ghir waters during 2000-2006, it could be expected a progressive reduction of the mean annual CHL concentration in both locations. Our CHL images from the SeaWiFS/OV-2 showed a different pattern trend. Mean annual CHL levels increased (like dry dust deposition) at Cape Ghir from $0.65 \mathrm{mg} \mathrm{m}^{-3}$ (2000) to 0.9 $\mathrm{mg} \mathrm{m}^{-3}$ (2006) indicating a process of progressive eutrophization on the upwelling sector. However, in the Canary Islands waters the mean annual CHL levels becomes significantly reduced from $0.59 \mathrm{mg}$ $\mathrm{m}^{-3}$ (2000) to $0.31 \mathrm{mg} \mathrm{m}^{-3}$ (2006) (like dry dust deposition), indicating a process of progressive tropical-like ocean landscape (figure 5).

Annual fluxes changes of Saharan dust could produce a significant impact on the bigeochemical cycle of trace elements, providing a source of nutrients required for N2-fixing diazotrophic cyanobacterial growth [3,5]. Thus, [15] reported in 2004 the development of an extensive and inedit 
bloom of the diazotrophic cyanobacterium Trichodesmium erythraeum Ehrenberg in the northwest African Upwelling never described before [16]. The early stages of this anomalous diazotrophic event and its possible relationship to episodic Saharan dust deposition may represent the dominant source of these new CHL pool observed in the Upwelling System location. However, in oceanic oligotrophic waters the reduction of the dust fluxes observed in this work could generate a significant reduction of the CHL levels and as a direct consequence, this sector would become poorer.

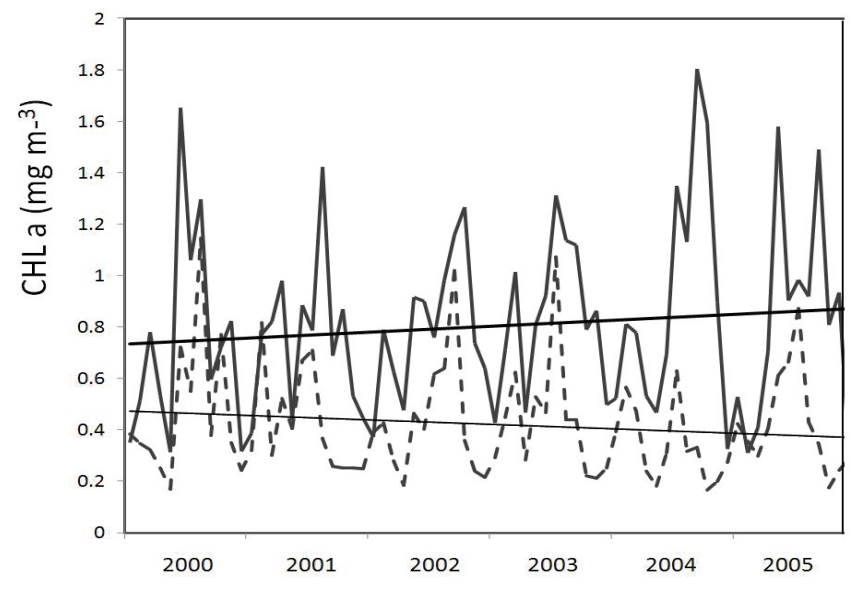

Figure 5. Annual mean satellite-derived SeaWiFS/OV-2 CHL data series obtained at Cape Ghir (solid line) and north of the Canary Islands (dashed line) in the Northwest African Upwelling area from 2000 to 2005 .

\section{Conclusions}

We hypostatize that the apparent changes observed in CHL during the last 7-year period could be associated to intensive dust deposition and exceptional weather warming observed in this area since 2000. This study is addressed to a 7-year period and our conclusions on possible links between dust deposition and marine biochemistry activity cannot be generalized. It would be necessary the study of iron bioavailability by using results of an atmospheric iron model (currently being under development) which simulates the atmospheric processing of iron and its conversion from insoluble to soluble form for primary producers.

\section{References}

[1] Basterretxea, G. and Arístegui, J, 2000 Mesoscale variability in phytoplankton biomass distribution and photosynthetic parameters in the Canary - NW African coast transition zone. Marine Ecology Progress Series, 197, 27-40.

[2] Prospero, J. M. and Carlson, T. N. 1981 Saharan air outbreaks over the tropical North Atlantic. Pure and Applied Geophysic,s 119 (3), 677-691.

[3] Lenes, J., Darrow, B., Cattrall, C., Heil, C. A., Callahan, M., Vargo, G., Byrne. R., Prospero, J., Bates, D., Fanning, K. and Walsh, J. 2001 Iron fertilization and the Trichodesmium response on the West Florida shelf. Limnology and Oceanography, 46, 1261-1277.

[4] Liu, X.and Millero, F.J. 2005 The solubility of iron in seawater. Marine Chemistry ,77, 43-54.

[5] Capone, D.G, Zehr, J.P, Paerl, H.W, Bergman, B., and Carpenter, E.J 1997 Trichodesmium, a globally significant marine cyanobacterium. Science, 276,1221-1229.

[6] Kremling, K. and Streu, P., 1993 Saharan dust influenced trace elements fluxes in deep North Atlantic subtropical waters. Deep Sea Research, Part I, 40, 1155-1168. 
[7] Pérez, C., Nickovic, S., Baldasano, J.M., Sicard, M., Rocadenbosch, F. and Cachorro, V.E. 2006 A long Saharan dust event over the western Mediterranean: Lidar, Sun photometer observations, and regional dust modelling. Journal of Geophysical Research, 111, D15214, doi:10.1029/2005JD006579.

[8] Pérez, C., Nickovic, S., Pejanovic, G., Baldasano, J.M., and Özsoy, E., 2006 Interactive dust radiation modelling: A step to improve weather forecasts. Journal of Geophysical Research, 111, D16206, doi:10.1029/2005JD006717.

[9] Papayannis, A., Zhang, H.Q., Amiridis, V., Ju, H.B., Chourdakis, G., Georgoussis, G., Pérez, C., Chen, H.B., Goloub, P., Mamouri, R.E., Kazadzis, S., Paronis, D., Tsaknakis, G., and Baldasano, J.M., 2007 Extraordinary dust event over Beijing, China, during April 2006: Lidar, Sun photometric, satellite observations and model validation. Geophysical Research Letters, 34, L07806, doi:10.1029/2006GL029125.

[10] Pérez, C., Jiménez-Guerrero, P., Jorba, O., Baldasano, J.M., Cuevas, E., Nickovic, S., Querol, X., 2007 Long-term simulations (1958-2006) of Saharan dust over the Mediterranean and the Eastern North Atlantic with the DREAM regional dust model. In: XXIV International Union of Geodesy and Geophysics (IUGG) General Assembly, Perugia, Italy, 2-13 July 2007.

[11] Nickovic, S., Kallos, G., Papadopoulos, A., and Kakaliagou, O., 2001 A model for prediction of desert dust cycle in the atmosphere. Journal of Geophysical Research, 106, D16, 1811318129.

[12] Coca, J. and Ramos, A., 2004 Relationships between satellite-derived oceanic events and the albacore tuna (Thunnus alalunga, Bonaterre, 1788) artisanal fishing grounds in the NE Atlantic. In Remote Sensing of the Ocean and Sea Ice (Ed. C. Bostater Jr. and Rosalia Santoreli). Proceedings of the SPIE, 5569, 116-129.

[13] Torres, M., Gelado, M., Collado, C., Siruela, V., Cardona, P., and Hernández-Brito, J., 2002 Variability of dust inputs to the CANIGO zone. Deep-Sea Research II, 49, 3455-3464.

[14] Arístegui, J., Tett, P., Hernández-Guerra, A., Basterretxea, G., Montero, M.F., Wild, K., Sangrá, P., Hernández-León, S., Cantón, M., García - Braun, J.A, Pacheco, M., and Barton, E.D., 1997 The influence of island-generated eddies on chlorophyll distribution: a study of mesoscale variation around Gran Canaria. Deep-Sea Research, 44, 71-96.

[15] Ramos A., Martel, A., Codd, G., Soler, E., Coca, J., Redondo, A., Morrison, L., Metcalf, J., Ojeda, A., Suárez, S., and Petit. M., 2005 Bloom of the marine diazotrophic cyanobacterium Trichodesmium erythraeum Ehrenberg in the Northwest African Upwelling. Marine Ecology Progress Series, 301, 303-305.

[16] Hood, R.R., Subramaniam, A., May, L.R., Carpenter, E.J. and Capone, D.G. 2002 Remote sensing of nitrogen fixation by Trichodesmium. Deep-Sea Research II, 49, 23-147. 